\title{
The Optimal Planting Coverage Rate and Wastewater Concentration for Water Spinach Floating Bed on Geese Wastewater Purification
}

\author{
Xiaofeng Huang ${ }^{1} \#$, Zhuping Chen ${ }^{1} \#$, Zuolan Liu' ${ }^{1}$ Jiajia Xue ${ }^{1}$, \\ Ying Chen ${ }^{1}$, Qigui Wang ${ }^{1,2}$, Chao Wang ${ }^{1,2 *}$ \\ ${ }^{1}$ Chongqing Academy of Animal Sciences, Chongqing 402460, China \\ ${ }^{2}$ Scientific Observation and Experiment Station of Livestock Equipment Engineering in Southwest, \\ Ministry of Agriculture, Chongqing 402460, China
}

Received: 23 March 2021

Accepted: 16 July 2021

\begin{abstract}
The goal of this study was to explore the optimal planting coverage rate and wastewater concentration required by water spinach floating bed system for the purification of geese farm wastewater. The results showed that the floating bed with water spinach in high concentration wastewater had better removal rates on ammonia nitrogen $\left(\mathrm{NH}_{4}{ }^{+}-\mathrm{N}\right)$, total nitrogen $(\mathrm{TN})$ and total phosphorus $(\mathrm{TP})(\mathrm{P}<0.05)$. There was no significant difference on the removal of nutrients except turbidity (NTU) among the different plant coverage rages $(\mathrm{P}>0.05)$. The floating bed system with water spinach removed heavy metals $(\mathrm{Hg}, \mathrm{As}$ and $\mathrm{Zn}$ ) in different concentration wastewater, with removal rates of $22.21 \% \sim 68.20 \%, 40.00 \% \sim 52.94 \%$ and $100.00 \%$. Water spinach in low concentration wastewater had significant higher root length, stem height and weight gain $(\mathrm{P}<0.05)$ than medium and high concentration wastewater. The TN and TP contents of water spinach stem leaf in high concentration wastewater were significantly higher than other groups $(\mathrm{P}<0.05)$. The concentration of heavy metals $(\mathrm{Pb}, \mathrm{Cd}, \mathrm{As}$ and $\mathrm{Hg})$ in water spinach in all groups was far below the national food safety standard. In general, the water spinach floating bed is suitable for the purification of medium and low concentration wastewater, and the optimal coverage rate is $40 \% \sim 60 \%$.
\end{abstract}

Keywords: wastewater concentration, coverage rate, water spinach, plant floating bed

\section{Introduction}

In 2020, the annual slaughter number of geese was about 740 million worldwide, with an increase of about

\#These authors contributed equally to this work. e-mail: wangccq@foxmail.com
$17.5 \%$ compare with that in 2019, and Asia accounts for about $96 \%$ of total amount and China possess the largest number of geese sold in Asia [1]. Nowadays, the expansion of the scale of geese breeding, coupled with the physiological habits of playing with water and washing water for cleaning house, leading to a large increase in breeding wastewater [2]. Wastewater from livestock and poultry breeding contains large amounts 
of nutrients, such as phosphorus, nitrogen, potassium and so on, which cannot be directly discharged and used in agriculture. The feces and urine of geese are alkaline, and the concentration of pollutants are different from those of livestock and other poultry. The wastewater treatment method of geese farm in the early stage is roughly the same as that of other livestock and poultry farms, and there may be some differences in the further purification treatment of biogas slurry after subsequent anaerobic fermentation. However, there are few researches concentrating on the treatment of wastewater from geese farm, especially the follow-up biogas slurry treatment [3]. In addition, many traditional treatment methods are difficult to be applied in practice because of high cost and low efficiency [4, 5]. Therefore, it will be great meaningful and valuable to explore how to treat wastewater of geese farm economically and efficiently.

As an innovative wastewater treatment technology, plant floating bed system consists of aquatic or terrestrial plants growing in a hydroponic manner with buoyant frames floating on the surface of wastewaters [6-8]. Plant floating island system is usually used to treat lakes and rivers water, which has the characteristics of low cost, convenient operation and no secondary pollution [9]. The key role of plants as part of the natural processes which remove nutrients and other pollutants from the wastewater. Many researchers also have proven that plant floating island could effectively reduce the content of nitrogen, phosphorus and other nutrients from wastewater [10-13]. Previous researchers compared the purification performances of plant floating bed for nitrogen and phosphors removal under a condition with a macrophyte coverage rate of $12.8 \%$, and the results showed that the plant floating bed system combined with calamus seedlings can decline the TN, TP, and $\mathrm{NH}_{4}^{+}-\mathrm{N}$ of eutrophic water in summer, and the highest removal rate is $36.3 \%, 35.7 \%$ and $44.3 \%$ respectively [14]. The average removal rates in an integrated floating island system for $\mathrm{TN}, \mathrm{NH}_{4}^{+}-\mathrm{N}$, $\mathrm{TP}$ in summer and autumn season were $36.9 \%, 44.8 \%$ and $43.3 \%$ respectively [15].

Water spinach is a vining plant, consumed as a leafy vegetable with high tolerance to heat and wet [16, 17]. It likes fertilizers and water, has strong regeneration ability, short picking cycle and long growth cycle spanning spring, summer and autumn. Researchers have found that water spinach, as a floating bed plant, has a good effect on the purification of fishpond water, with the removal rates of total nitrogen and total phosphorus were $27.07 \% \sim 69.84 \%$ and $48.48 \% \sim 76.67 \%$ respectively [18, 19], which can fully recycle the aquaculture wastewater. In addition, water spinach is one of the main edible vegetables in the south region of middle and lower reaches of the Yangtze River. As we know, geese are herbivorous birds, which have a great demand for pasture in geese farm. Therefore, it also can be beneficial to harvest water spinach in floating bed system for feed of geese. At present, there are few studies on the wastewater purification of geese farm, especially on the appropriate related parameters, such as the planting density of floating bed plants and the tolerance to wastewater with different concentrations. To investigate the effect of the water spinach floating bed system on the pollutants in the wastewater of geese farm, the present study was carried out on geese farm for 40 days. In this work, the concentration of pollutants in wastewater and growth of water spinach was monitored to find optimal plant coverage and wastewater concentrations.

\section{Materials and Methods}

\section{Experimental Materials and Floating Bed Design}

The experiment was performed in the poultry scientific research base of Chongqing Academy of Animal Science. The wastewater was obtained from biogas liquid after precipitation in the base, and the average concentration of pollutants are shown in Table 1. The water spinach was planted by the base. The water spinach grew in the fields for 20 days until they reached the ideal size to be cut into segments and transferred to the defined location of the experiment.

The self-made floating bed system was composed of double polyethylene net $(1 \times 1 \mathrm{~cm})$ and PVC tube, sized with $70 \times 55 \times 5 \mathrm{~cm}, 64 \times 45 \times 5 \mathrm{~cm}$ and $48 \times 40 \times 5 \mathrm{~cm}$ horizontal and vertical. The experiment was carried out in plastic cartons, sized with $80 \times 60 \times 50 \mathrm{~cm}$ horizontal and vertical.

Table 1. The initial concentration of nutrients in geese wastewater ${ }^{1}$.

\begin{tabular}{|c|c|c|c|c|c|c|}
\hline WCON $^{2}$ & $\begin{array}{c}\mathrm{COD} \\
(\mathrm{mg} / \mathrm{L})\end{array}$ & $\begin{array}{c}\mathrm{BOD}_{5} \\
(\mathrm{mg} / \mathrm{L})\end{array}$ & $\begin{array}{c}\mathrm{NH}_{4}^{+}-\mathrm{N} \\
(\mathrm{mg} / \mathrm{L})\end{array}$ & $\begin{array}{c}\mathrm{TP} \\
(\mathrm{mg} / \mathrm{L})\end{array}$ & $\begin{array}{c}\mathrm{TN} \\
(\mathrm{mg} / \mathrm{L})\end{array}$ & NTU \\
\hline Low & $110.00 \pm 0.32$ & $28.65 \pm 0.49$ & $47.05 \pm 1.07$ & $6.60 \pm 0.06$ & $56.35 \pm 0.26$ & $40.23 \pm 0.75$ \\
\hline Medium & $170.50 \pm 0.87$ & $32.90 \pm 0.81$ & $77.75 \pm 0.43$ & $10.05 \pm 0.03$ & $97.55 \pm 9.50$ & $68.55 \pm 1.30$ \\
\hline High & $338.01 \pm 2.31$ & $66.65 \pm 0.61$ & $152.00 \pm 2.31$ & $20.15 \pm 0.32$ & $207.00 \pm 9.81$ & $137.13 \pm 1.08$ \\
\hline
\end{tabular}

${ }^{1}$ Data are shown as mean \pm SEM and each mean represent 3 samples;

${ }^{2}$ means concentration of wastewater (high/medium /Low- 3/6/9 times diluent from biogas). 


\section{Testing Design}

The water spinach segments were rinsed with tap water, then divided into homogenous groups and acclimatized for 5 days in the same environmental conditions. Three plants with different weight $(60 \mathrm{~g}$, $45 \mathrm{~g}$ and $30 \mathrm{~g}$,) and quantities (48, 36 and 24) were respectively planted into the floating bed at $80 \%$, $60 \%$ and $40 \%$ coverage, then put into plastic cartons filled with biogas liquid dilution by 3, 6 and 9 times respectively. A total of 9 treatment groups were set up in the experiment according to the wastewater concentration and plant coverage, each of 3 replicates. The information of group was as following: (1) L-CON: low-concentration wastewater without plant; (2) L-40\%: low-concentration wastewater with $40 \%$ coverage plant; (3) L-60\%: low-concentration wastewater with $60 \%$ coverage plant; (4) L-80\%: low-concentration wastewater with $80 \%$ coverage plant; (5) M-CON: medium-concentration wastewater without plant; (6) M-40\%: medium-concentration wastewater with $40 \%$ coverage plant; (7) M-60\%: medium-concentration wastewater with $60 \%$ coverage plant; (8) M-80\%: medium-concentration wastewater with $80 \%$ coverage plant; (9) H-CON: high-concentration wastewater without plant; (10) H-40\%: high-concentration wastewater with $40 \%$ coverage plant; (11) H-60\%: highconcentration wastewater with $60 \%$ coverage plant; (12) $\mathrm{H}-80 \%$ : high-concentration wastewater with $80 \%$ coverage plant. The experiment was initiated from August 2019 to September 2019 and lasted for 40 days. During the experiment period, the temperature ranged from $20.1^{\circ} \mathrm{C}$ to $34.2^{\circ} \mathrm{C}$ and the mean temperature was approximately $27.4^{\circ} \mathrm{C}$.

\section{Pollutants Determination}

At day 0 and 30, water samples were collected to detect the concentration of pollutants which were composed of TN, TP, turbidity, $\mathrm{NH}_{4}^{+}-\mathrm{N}, 5-$ day biochemical oxygen demand $\left(\mathrm{BOD}_{5}\right)$, chemical oxygen demand (COD) and heavy metal ( $\mathrm{Hg}, \mathrm{As}, \mathrm{Zn}, \mathrm{Cr}, \mathrm{Cd}, \mathrm{Se}$, $\mathrm{Cu}$, and $\mathrm{Pb}$ ). Plant growth parameters (plant height, root length and relative growth rate), nutritional parameters (nitrogen and phosphorus content) and safety indicators $\left(\mathrm{Pb}, \mathrm{Cd}, \mathrm{As}, \mathrm{Hg}\right.$ and $\mathrm{NaNO}_{2}$ ) were also measured to monitor the growth of plants. The pollutants from wastewater were measured according to the standard methods for water and wastewater monitoring and analysis (APHA, 2005), And the relative indexes in plant tissues were determined according to previous methods [20, 21].

Plants were washed with tap water at the start and end of the experiment, and the average fresh plant weight was measured. The relative growth rate (RGR) was calculated as:

$$
\operatorname{RGR}(\%)=100 \times\left(\mathrm{W}_{\mathrm{e}}-\mathrm{W}_{\mathrm{i}}\right) / \mathrm{W}_{\mathrm{i}}
$$

...where $\mathrm{W}_{\mathrm{e}}$ is the average fresh weight of plants at the end of experiments, $W_{i}$ is the average initial fresh weight of plants.

The removal rate (RR) of pollutants in this study was calculated as:

$$
\operatorname{RR}(\%)=100 \times\left(\mathrm{C}_{\mathrm{i}}-\mathrm{C}_{\mathrm{t}}\right) / \mathrm{C}_{\mathrm{i}}
$$

...where $C_{t}$ is the average concentration of pollutants after treatment, $\mathrm{C}_{\mathrm{i}}$ is the average initial concentration of pollutants.

\section{Statistical Analysis}

All data calculation as averages and standard error of mean (SEM) were performed in Microsoft Excel 2016. Statistical analyses were carried out using Analysis of variance (ANOVA) in Software SPSS 20.0 (SPSS Inc., Chicago, IL, USA) including Bartlett's test for homogeneity of variances analysis and Duncan's test for differences between means. All statements of differences were based on a significance level of $\mathrm{P}<0.05$.

\section{Results}

\section{Removal Efficiencies of Nutrients by Water Spinach Floating Bed System}

The removal performances of plant floating bed system on nutrients in geese wastewater from geese farm are shown in Table 2. The water spinach floating bed has a significant effect on the removal of pollutants in wastewater compared with the control group. The wastewater concentration has significant influence on the removal rate of pollutants in wastewater by water spinach floating bed system $(\mathrm{P}<0.05)$. As the growth time of floating bed plants goes on, the pollutants in wastewater were decreased. The removal rate of $\mathrm{COD}$ and $\mathrm{BOD}_{5}$ in low-concentration wastewater was significantly lower than medium and high concentration wastewater $(\mathrm{P}<0.05)$, which were $51.41 \%, 59.99 \%$, $59.27 \%$ and $58.72 \%, 58.94 \%, 59.09 \%$, respectively. There was no significant effect on the removal of pollutants between medium and high concentration wastewater $(\mathrm{P}>0.05)$. The removal effect of $\mathrm{NH}_{4}^{+}-\mathrm{N}$ in high concentration wastewater is better than other groups $(\mathrm{P}<0.05)$, which were $99.93 \%, 99.84 \%$ and $99.70 \%$, respectively. For total phosphorus and total nitrogen, the removal rate decreased significantly with the decrease of wastewater concentration $(\mathrm{P}<0.05)$, and the removal rate in high concentration wastewater was the highest in our studies, which were $63.47,61.67 \%$, $43.47 \%$ and $80.37 \%, 74.59 \%, 57.74 \%$ respectively. The removal effect of the turbidity in low and medium concentration wastewater were higher than that in high concentration wastewater $(\mathrm{P}<0.05)$, which were $75.77 \%, 77.29 \%$ and $65.60 \%$, respectively. In general, 

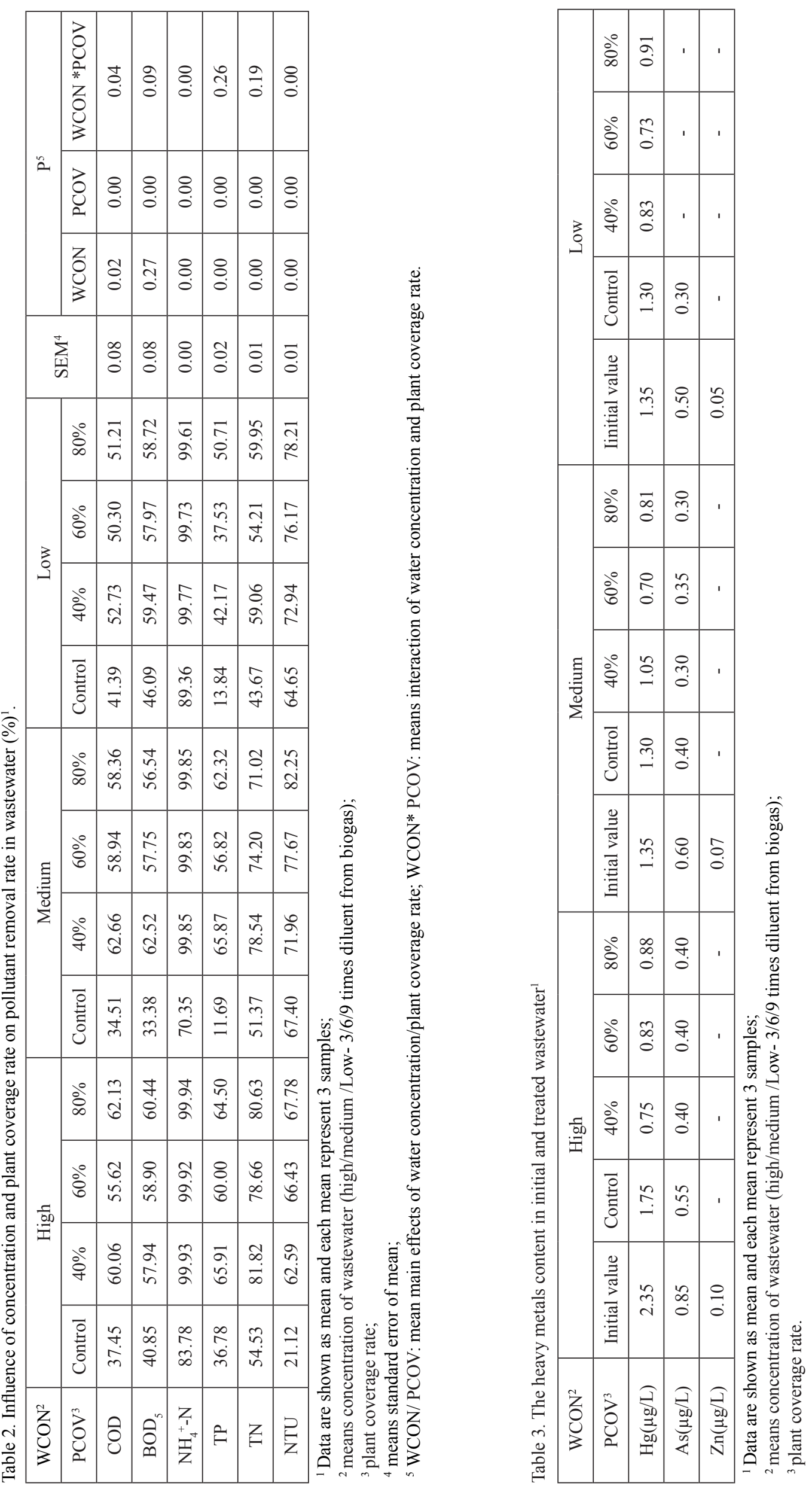
Table 4 The heavy metals and nitrites contents of water spinach in each treatment group ${ }^{1}$.

\begin{tabular}{|c|c|c|c|c|c|c|c|c|c|}
\hline $\mathrm{WCON}^{2}$ & \multicolumn{3}{|c|}{ High } & \multicolumn{3}{c|}{ Medium } & \multicolumn{3}{c|}{ Low } \\
\hline $\mathrm{PCOV}^{3}$ & $40 \%$ & $60 \%$ & $80 \%$ & $40 \%$ & $60 \%$ & $80 \%$ & $40 \%$ & $60 \%$ & $80 \%$ \\
\hline $\mathrm{Pb}(\mathrm{mg} / \mathrm{kg})$ & & - & 0.027 & - & - & 0.035 & - & 0.035 & - \\
\hline $\mathrm{Cd}(\mathrm{mg} / \mathrm{kg})$ & & - & 0.002 & 0.002 & - & - & - & - & - \\
\hline $\mathrm{Hg}(\mathrm{mg} / \mathrm{kg})$ & & - & - & - & - & - & - & - & - \\
\hline $\mathrm{As}(\mathrm{mg} / \mathrm{kg})$ & & 0.016 & 0.013 & 0.017 & 0.012 & 0.014 & 0.016 & 0.012 & 0.013 \\
\hline $\mathrm{NaNO}_{2}(\mathrm{mg} / \mathrm{kg})$ & & 10.0 & 20.0 & - & 2.5 & 2.2 & - & 1.0 & 1.0 \\
\hline
\end{tabular}

${ }^{1}$ Data are shown as mean and each mean represent 3 samples;

${ }^{2}$ means concentration of wastewater (high/medium /Low- 3/6/9 times diluent from biogas);

${ }^{3}$ plant coverage rate.

the removal effect of pollutants reached the best in high concentration wastewater.

The coverage rates of water spinach had significant effects on the removal of COD, $\mathrm{BOD}_{5}, \mathrm{NH}_{4}^{+}-\mathrm{N}$, TP and $\mathrm{TN}$ in wastewater $(\mathrm{P}<0.05)$. There was no significant difference on the removal of nutrients among the treatment groups $(\mathrm{P}>0.05)$. The removal effect of the turbidity with $80 \%$ and $60 \%$ coverage rates were higher than that with $40 \%$ coverage $\operatorname{rates}(\mathrm{P}<0.05)$, which were $76.08 \%, 73.42 \%$ and $69.16 \%$, respectively. On the whole, the coverage rate of water spinach should be $40 \% \sim 60 \%$ and the planting cost can be reduced.

In our studies, there was a synergistic effect between the two factors on the removal effect of COD, $\mathrm{NH}_{4}^{+}-\mathrm{N}$ and NTU $(\mathrm{P}<0.05)$, while there was no synergistic effect on TP and TN.

\section{Removal Efficiencies of Heavy Metal in Wastewater by Water Spinach Floating Bed System}

The heavy metal content in wastewater before and after the experiment are shown in Table 3. Some important heavy metals $(\mathrm{Hg}, \mathrm{As}, \mathrm{Zn}, \mathrm{Cr}, \mathrm{Cd}, \mathrm{Se}, \mathrm{Cu}$ and $\mathrm{Pb}$ ) were measured, just three heavy metals $(\mathrm{Hg}$, As and $\mathrm{Zn}$ ) were found in wastewater. The floating bed system of water spinach reduced the concentration of heavy metals ( $\mathrm{Hg}$, As and $\mathrm{Zn}$ ) in wastewater with different concentrations, which are $22.2 \% \sim 68.2 \%$, $40.0 \% \sim 52.94 \%$ and $100.0 \%$ respectively. There was not obvious relation between the removal effect and the plant coverage rate. The removal effect is mainly affected by wastewater concentration.

\section{Effects on Plant Growth}

Wastewater concentration and plant coverage rate had significant effects on root length, stem height, weight gain and growth rate of water spinach, and the results were showed in Table 6 . Under the coverage rates of $40 \%$ and $80 \%$, the stem height, weight gain and growth rate of water spinach were inversely proportional to the wastewater concentration $(\mathrm{P}<0.05)$. At $60 \%$ coverage rate, which of low concentration groups was higher than medium concentration and high concentration groups $(\mathrm{P}<0.05)$.

There were no significant differences in stem height, root length, weight gain and growth rate of water spinach among different coverage rates $(40 \%, 60 \%$ and $80 \%)$ in high concentration wastewater $(\mathrm{P}>0.05)$. In medium concentration wastewater, the stem height with the coverage rate of $60 \%$ is the best, followed by $80 \%$ and the last $40 \%(\mathrm{P}<0.05)$. Weight gain with $60 \%$ and $80 \%$ coverage rates were higher than $40 \%(\mathrm{P}<0.05)$. The growth rate of water spinach with $80 \%$ coverage rate were higher than $60 \%$ and $40 \%(\mathrm{P}<0.05)$. There was no significant difference in root length among different coverage rates. In low concentration wastewater, the stem height with the $40 \%$ coverage rate was higher than $60 \%(\mathrm{P}<0.05)$, root length with the $40 \%$ coverage rate was higher than $60 \%$ and $80 \%(\mathrm{P}<0.05)$, Weight gain with $80 \%$ coverage rate were higher than $60 \%$ and $40 \%(\mathrm{P}<0.05)$, The growth rate of water spinach with $60 \%$ and $80 \%$ coverage rates were higher than $40 \%(\mathrm{P}<0.05)$. For stem height, root length, weight gain and growth rate, there was a significant interaction between biogas slurry dilution ratio and plant coverage rate $(\mathrm{P}<0.05)$.

The influence of water concentration and plant coverage rate on nutrient content of water spinach are shown in Table 7. Wastewater concentration has a significant effect on the TN and TP contents of water spinach stem leaf and root but has no significant effect on water content. The growth of water spinach in high concentration wastewater was slow and some died, which led to insufficient samples in the $40 \%$ and $60 \%$ coverage groups at the end of the experiment and no measurement was carried out. The TN and TP content of water spinach stem leaf in high concentration wastewater were significantly higher than those in medium and low concentration wastewater $(\mathrm{P}<0.05)$. The TN and TP content in root is proportional to the wastewater concentration. Coverage rate had no significant effect on TN and TP content in stem leaf of 
Table 5. The heavy metals and nitrites content standards in vegetables.

\begin{tabular}{|c|c|c|c|c|}
\hline $\mathrm{mg} / \mathrm{kg}$ & Standard & Pollution-free & Green vegetables & Detection limit \\
\hline $\mathrm{Pb}$ & 0.3 & 0.2 & 0.1 & 0.02 \\
\hline $\mathrm{Cd}$ & 0.2 & 0.05 & 0.05 & 0.001 \\
\hline $\mathrm{Hg}$ & 0.01 & 0.01 & 0.01 & 0.003 \\
\hline $\mathrm{As}$ & 0.5 & 0.5 & 0.2 & 0.01 \\
\hline $\mathrm{NaNO}_{2}$ & 1 & 4 & 1 & 1 \\
\hline
\end{tabular}

water spinach but had effect on TN and TP content in root. The TN content of $80 \%$ coverage rate is higher than $60 \%$, and the TP content is higher than $60 \%$ and $40 \%$. Overall, there was no significant interaction between wastewater concentration and plant coverage rate on moisture content, $\mathrm{TN}$ and $\mathrm{TP}$ content of stem leaf $(\mathrm{P}>0.05)$.

In addition, this experiment measured the moisture content and TN and TP content $(88.07 \%, 2.11 \mathrm{mg} / \mathrm{kg}$, $0.50 \mathrm{mg} / \mathrm{kg}$ and $87.14 \%, 1.97 \mathrm{mg} / \mathrm{kg}, 0.41 \mathrm{mg} / \mathrm{kg}$ )in the stem leaf and root of water spinach cultivated in soil (it grows for about 60 days), and found that the moisture content and $\mathrm{TN}$ content were significantly lower than that in hydroponic culture $(90.05 \%, 3.41 \mathrm{mg} / \mathrm{kg}$, $0.47 \mathrm{mg} / \mathrm{kg}$ and $88.56 \%, 3.47 \mathrm{mg} / \mathrm{kg}, 0.41 \mathrm{mg} / \mathrm{kg}$ ) $(\mathrm{P}<0.05)$.

\section{Water Spinach Safety Assessment}

The heavy metal and nitrite content in water spinach were determined and shown in Table 4. The content standards of heavy metals and nitrites in vegetables and the corresponding minimum detection limits in this experiment are shown in Table 5. The concentration of several heavy metals ( $\mathrm{Pb}, \mathrm{Cd}$ and $\mathrm{As})$ in water spinach in all groups is far below the national food safety standard and $\mathrm{Hg}$ was not detected at 40 day. The results showed that the higher the concentration of wastewater, the higher the nitrite content of water spinach. Therefore, water spinach cultured in high concentration wastewater cannot meet the safety standards of edible vegetables in China.

\section{Discussion}

\section{The Nutrients Removal by Water Spinach Floating Bed System}

The plant floating system could form a biofilm with a large surface area for the purification of water by both epiphyte and microbes [20]. The epiphyte could contact wastewater to absorb, transform and degrade the pollutants, and secrete large amount of enzyme and organic acid to accelerate the decomposition of the macromolecular pollutants and improve the bioavailability of nitrogen and phosphorus in wastewater [21, 22]. Meanwhile, plant floating system will bring various bacteria involved in pollutants degradation and removal into wastewater [23]. In the present study, the plant floating bed system with different coverage rates could significantly improve the removal rates of $\mathrm{COD}, \mathrm{BOD}_{5}, \mathrm{NH}_{4}^{+}-\mathrm{N}, \mathrm{TP}, \mathrm{TN}$ and turbidity in different concentrations wastewater compare with control in winter. This was similar to previous studies on the purification of rivers by plant floating bed systems, which can effectively remove pollutants from the water [24-26].

In this experiment, the removal effect of water spinach floating bed in high-concentration wastewater was better than that in low-concentration wastewater, possibly because the more nutrients in the high concentration wastewater were absorbed by plants $[27,28]$. In addition, there is a problem that the plants in a long-term over-nutrition environment will lead to water loss and even death, which indicates that it is not necessarily proportional between decontamination effect and plant growth. It is also closely related to the species and physiological characteristics of plant. In our study, there was no significant difference in the removal effect of many pollutants $\left(\mathrm{COD}, \mathrm{BOD}_{5}, \mathrm{NH}_{4}^{+}-\mathrm{N}\right.$, $\mathrm{TP}, \mathrm{TN})$ among floating beds of water spinach with different coverage rates, which may be related to the planting scale of floating bed plants and the amount of wastewater. Our study proved that the coverage rate is proportional to the turbidity removal rate and consistent with the former study, the removal rates of turbidity with $80 \%$ plant coverage rate by the water spinach floating bed system (76.05\%) was more than 1.05 times of that by $40 \%(69.16 \%)$ and $60 \%(73.42 \%)$.

The floating bed plants are capable of absorbing, metabolizing and enriching heavy metals, and the content of heavy metals within the plants increased as the reduction of the water's pollution level, so plant floating bed system was regarded as an efficient way of reducing heavy metal pollution in wastewater [2931]. The contents of heavy metals in the wastewater of each treatment group were reduced by $23 \% \sim 68 \%$ of $\mathrm{Hg}, 32.59 \% \sim 56.25 \%$ of $\mathrm{As}$ and $100 \%$ of $\mathrm{Zn}$, respectively, indicating that water spinach floating bed can effectively reduce heavy metals in wastewater. In practical application, water spinach can continuously remove the heavy metal from wastewater because of its long growth cycle to avoid the environmental and land 

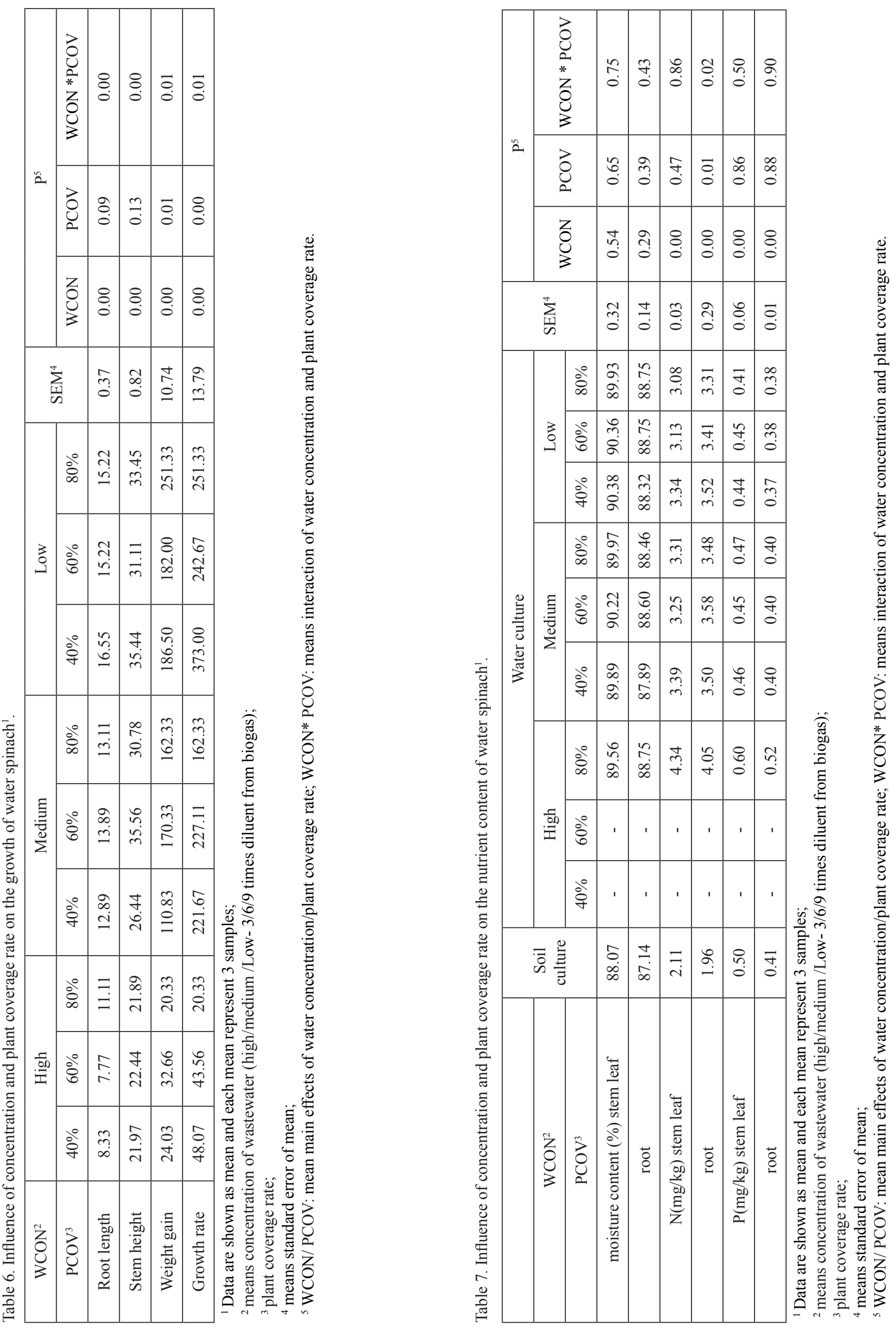
pollution caused by excessive content of heavy metals in wastewater after long-term deposition.

\section{Effects on the Growth and Security of Water Spinach}

The efficiency of pollutants removal by the plant floating bed systems depends upon plant biomass production and pollutants concentrations in wastewater $[29,30]$. In this experiment, the water spinach in high concentration wastewater grew slowly and some plants even died in the interim and late stage of the experiment, which indicated that the high concentration wastewater would inhibit the growth of plants. This is consistent with previous research [31]. The average stem height and root length of water spinach in low concentration group were 1.08 and 1.51 times and 1.18 and 1.73 times of those in medium and high concentration groups, respectively. The average weight gain and growth rate of water spinach in low concentration were 1.95 and 8.05 times and 1.40 and 7.74 times of those in medium and high concentration group. As a crucial factor, the concentration of wastewater played an important role in plant growth [28], and low concentration wastewater was more suitable for plant growth in floating boat system. The water spinach with $40 \%$ coverage grew best in low concentration wastewater, and water spinach with $60 \%$ and $80 \%$ coverage was better in medium concentration wastewater. This may be because the nutrients in low concentration wastewater could not meet the need of long-term growth of water spinach with high coverage rate, and there was a competitive mechanism among plants, while the medium concentration could fully meet the nutritional requirements. Therefore, wastewater concentration and plant coverage rate have a co-regulation effect on plant growth.

Food safety has always been the most concerned issue for consumers. As a common vegetable, it is essential to conduct safety tests of water spinach produced by hydroponics in this experiment to avoid excessive content of heavy metals and other harmful substances to human and animals [32]. The heavy metal content of water spinach in this experiment is far lower than the industry standard, and the contents of $\mathrm{Pb}, \mathrm{Cd}$ and As were $0.175,0.046$ and 0.032 times of the standard, respectively. The floating bed water spinach growing in the low concentration wastewater can reach the standard of green vegetable, and the water spinach growing in the middle concentration wastewater can reach the standard of pollution-free vegetable. The nitrite content of water spinach was proportional to the concentration wastewater, which also indicated that high concentration wastewater could not be directly used for hydroponic water spinach. In addition, water spinach belongs to a vine, with shallow root distribution, beard root and strong regeneration ability. In the practice, the harvesting cycle of stem and leaves can be shortened to about 20 days to reduce the deposition of heavy metals [33]. Meanwhile, the hydroponic fluid should be renewed timely to avoid excessive deposition of nitrite to ensure the food safety.

As a green leaf vegetable, water spinach is rich in nutrients, such as nitrogen and phosphorus [34]. In our study, the water content and total nitrogen content in stem leaf and root of water spinach in hydroponic culture were significantly higher than those in soil. This is probably because water spinach in hydroponic culture has more developed roots than that in soil, it is easier to absorb nutrients from wastewater [35]. The content of TP in stem, leaf and root of water cabbage in medium and low concentrations were slightly lower than those in soil, which might be related to the TP content in soil and growth cycle. Even if the wastewater concentration is proportional to the content of nitrogen and phosphorus in water spinach, there was no direct relationship between the wastewater concentration and the nutritional quality of water spinach. The wastewater concentration is high that plants can't survive and produce large amounts of nitrites, which are harmful to humans.

\section{Conclusion}

The water spinach floating bed system had a better removal effect on pollutants in high concentration wastewater from geese farm compared to medium and low concentration groups, while the growth of part plants was inhibited or even dead in late stage. Low concentration wastewater was more beneficial for the growth of water spinach and the yield was the highest among three concentration wastewaters. The water spinach with $40 \%$ coverage rate in low concentration wastewater has highest growth rate in all groups. The water spinach cultured in low concentration wastewater reached the standard of green vegetable, and those cultured in medium concentration wastewater reached the standard of pollution-free vegetable.

In general, the water spinach floating bed is suitable for the application of medium and low concentration wastewater, and the optimal coverage rate is $40 \% \sim 60 \%$.

\section{Acknowledgments}

This study was supported by China Agriculture Research System of MOF and MARA (CARS-42-22), and the Key R \& D Project in Agriculture and Animal Husbandrys of Rongchang (cstc2019ngzx0017).

\section{Conflict of Interest}

The authors declare no conflict of interest. 


\section{Reference}

1. HOU S., LIU L. Current status, future trends and suggestions of waterfowl industry in 2018. Chinese Journal of Animal Science. 56 (03), 135, 2020.

2. LOYN R.H., SWINDLEY R.J., STAMATION K. Waste water not wasted: the Western treatment plant as a habitat for waterfowl. Victorian Naturalist, The. 131 (4), 147, 2014.

3. HUANG X., LUO Y., LIU Z., ZHANG C., ZHONG H., XUE J., et al. Influence of Two-Stage Combinations of Constructed Wetlands on the Removal of Antibiotics, Antibiotic Resistance Genes and Nutrients from Goose Wastewater. International journal of environmental research and public health. 16 (20), 4030, 2019.

4. YANG X.-E., WU X., HAO H.-L., HE Z.-L. Mechanisms and assessment of water eutrophication. Journal of Zhejiang University-Science B (Biomedicine \& Biotechnology). 9 (3), 197, 2008.

5. ZHAO F., XI S., YANG X., YANG W., LI J., GU B., et al. Purifying eutrophic river waters with integrated floating island systems. Ecological Engineering. 40, 53, 2012.

6. HU G.-J., ZHOU M., HOU H.-B., ZHU X., ZHANG W.-H. An ecological floating-bed made from dredged lake sludge for purification of eutrophic water. Ecological Engineering. 36 (10), 1448, 2010.

7. BOUTWELL J.E. Preliminary field studies using vegetated floating platforms: US Department of the Interior, Bureau of Reclamation; 1995.

8. PRASHANT, BILLORE S.K. Macroinvertebrates associated with artificial floating islands installed in River Kshipra for water quality improvement. Water Science \& Technology. 81 (6), 2020.

9. WU Q., HU Y., LI S., PENG S., ZHAO H. Microbial mechanisms of using enhanced ecological floating beds for eutrophic water improvement. Bioresource Technol. 211, 451, 2016.

10. WANG J., ZHI Y., SONG Y. Purification Effect of Water Hyacinth (Eichhornia crassipes) Coverage on the Different Flow Properties Water Bodies. Ecology and Environmental Sciences. 21 (1), 124, 2012.

11. STEWART F.M., MUHOLLAND T., CUNNINGHAM A.B., KANIA B.G., OSTERLUND M.T. Floating islands as an alternative to constructed wetlands for treatment of excess nutrients from agricultural and municipal wastesresults of laboratory-scale tests. Land Contamination \& Reclamation. 16 (1), 25, 2008.

12. LUO S., ZHANG Y., LI J., HUANG Z., HUO H., DONG Y. Effect of combination of submerged macrophyte with ecological floating bed on aquacultural pollution controlling. Journal of Ecology and Rural Environment. 27 (2), 87, 2011.

13. MASTERS B. The ability of vegetated floating Islands to improve water quality in natural and constructed wetlands: a review. Water Practice and Technology. 7 (1), 2012.

14. HU G.J., ZHOU M., HOU H.B., ZHU X., ZHANG W.H. An ecological floating-bed made from dredged lake sludge for purification of eutrophic water. Ecological Engineering. 36 (10), 1448, 2010.

15. ZHAO F., XI S., YANG X., YANG W., LI J., GU B., et al. Purifying eutrophic river waters with integrated floating island systems. Ecological Engineering. 40 (3), 53, 2012.

16. WENG J.H., LAI M.F. Estimating heat tolerance among plant species by two chlorophyll fluorescence parameters. Photosynthetica. 43 (3), 439, 2005.
17. GUO R., WANG X., HAN X., CHEN X., WANG-PRUSKI G. Physiological and transcriptomic responses of water spinach (Ipomoea aquatica) to prolonged heat stress. BMC Genomics. 21 (1), 2020.

18. HAIFENG BAI Y.L., FENG WANG, XINGLANG ZHANG, YONGFENG YUAN The removal effect of Ipomoea aquatica with different cover rate on nitrogen and phosphorus from jing carp pond in Songpu. Chinese Journal of Fisheries. $33(05), 70,2020$.

19. TUNG T.V., BA Q.T., THAO N., LE Q.V., LE Q.V. Recycling of aquaculture wastewater and sediment for sustainable corn and water spinach production. Chemosphere. 268 (4), 129329, 2020.

20. HU M.H., YUAN J.H., YANG X.E., HE Z.L. Effects of temperature on purification of eutrophic water by floating eco-island system. Acta Ecologica Sinica. 30 (6), 310, 2010.

21. ZHANG H., HAN J., CHEN F., YUAN Q. Review on Plants Selection and Application Effects in Ecological Floating Beds based on Water purification. IOP Conference Series: Earth and Environmental Science. 647 (1), 012186 (7pp), 2021.

22. YU D., NI F. Review of Ecological Floating Bed Restoration in Polluted Water. Journal of Water Resource \& Protection. 5 (12), 1203, 2013.

23. ZHEN S., XIE D., JIANG X., FU G., XIAO D., LIANG Z. Effect of eco-remediation and microbial community using multilayer solar planted floating island (MS-PFI) in the drainage channel. 2018.

24. SUN S., GU X., ZHANG M., C.L.T., BS.H.A., HUANG J. Biological iron nitrogen cycle in ecological floating bed: Nitrogen removal improvement and nitrous oxide emission reduction - ScienceDirect. Environmental Pollution. 268, 115842, 2021.

25. CAO W., WANG Y., SUN L., JIANG J., ZHANG Y. Removal of nitrogenous compounds from polluted river water by floating constructed wetlands using rice straw and ceramsite as substrates under low temperature conditions. Ecological Engineering. 88, 77, 2016.

26. LUO J., LI X., MA R., LI F., DUAN H., HU W., et al. Applying remote sensing techniques to monitoring seasonal and interannual changes of aquatic vegetation in Taihu Lake, China. Ecological Indicators. 60, 503, 2016.

27. WANG W.H., WANG Y., SUN L.Q., ZHENG Y.C., ZHAO J.C. Research and application status of ecological floating bed in eutrophic landscape water restoration. Science of The Total Environment. 704, 135434, 2019.

28. DUAN J.J., ZHAO J.N., XUE L.H., YANG L.Z. Nutrient removal of a floating plant system receiving low- pollution wastewater: Effects of plant species and influent concentration. IOP Conference Series: Earth and Environmental Science. 41, 012028, 2016.

29. WANG J., ZHENG Y., SONG Y. Purification Effect of Water Hyacinth (Eichhornia crassipes) Coverage on the Different Flow Properties Water Bodies. Ecology \& Environmental ences. 21 (01), 124, 2012.

30. ALMUKTAR AAAN S., AL-ISAWI H.K.R., SANI A., et al. Recycling of domestic wastewater treated by verticalflow wetlands for irrigating Chillies and Sweet Peppers. Agricultural Water Management. 149, 2015.

31. YING G., JIE C., WANG X., XU Q. Relationship between the physiological characters and purification ability of different plants in waters with two trophic levels. Computer Methods \& Programs in Biomedicine. 107 (3), $367,2000$. 
32. BAO P., GAO X.L., WEN G.Q. The Threat of Antibiotics and Heavy Metal Pollution to Human Health and Potential Solutions. BioMed Research International. 2020, $1,2020$.

33. NING D., YONG H., PAN R., WANG F., HUI W. Effect of eco-remediation using planted floating bed system on nutrients and heavy metals in urban river water and sediment: A field study in China. Science of the Total Environment. 485-486, 2014.
34. XIANG S., WU S., ZHANG Q., LIU Y., RUAN R. A nitrogen dynamic hydroponic culture on performance and quality of water spinach (Ipomoea aquatica). Journal of Plant Nutrition. 43 (6), 2020.

35. MAJID M., KHAN J. N., SHAH Q.A., MASOODI K.Z., AFROZA B., PARVAZE S. Evaluation of hydroponic systems for the cultivation of Lettuce (Lactuca sativa L., var. Longifolia) and comparison with protected soil-based cultivation. Agricultural Water Management. 245, 2021. 